\title{
Challenges and Advances in Targeting Remission in Axial Spondyloarthritis
}

Biologic therapies have vastly improved clinical outcomes for patients with axial spondyloarthritis (axSpA). Consequently, targeting clinical remission/inactive disease is now a major treatment goal as outlined in current treat-to-target recommendations ${ }^{1,2}$. In March 2016, the current status of treating to target and aiming for remission in axSpA was reviewed by 7 expert rheumatologists and 1 patient representative at an industry-sponsored roundtable discussion. This editorial summarizes the key findings from the meeting and recommendations for future research.

At present, there is no clear, universally accepted definition of remission in axSpA for both clinical trials and routine practice. Clinical remission/inactive disease is defined by the absence of clinical and laboratory evidence of significant inflammatory disease activity in current treat-to-target recommendations ${ }^{1,2}$; however, it remains unclear how to precisely assess this in practice. Various criteria to measure low disease activity (LDA) and clinical remission have been proposed that while potentially serving as realistic treatment goals in a treat-to-target strategy, require further validation in the clinical setting ${ }^{3,4}$. In 2001, the Assessment of Spondyloarthritis international Society (ASAS) developed a preliminary definition of clinical remission-ASAS partial remission (ASAS PR), which includes assessment of 4 domains: patient global, spinal pain, physical function, and "inflammation" (a proxy for true inflammation, based on morning stiffness $)^{5}$. In clinical trials, $12-15 \% \%^{5,6}$ of patients with ankylosing spondylitis (AS) receiving nonsteroidal antiinflammatory drugs (NSAID) achieve partial remission; a ceiling of $\sim 15-40 \%$ at 6 months also exists with biologic therapies, including tumor necrosis factor (TNF) inhibitors and secukinumab ${ }^{7,8}$ (Table $1^{9-20}$ ). Treating patients with short symptom duration may increase the proportion of patients reaching clinical remission to $\sim 50 \%$ 9,21,22 .

Several other composite indices evaluating disease activity exist. The Bath AS Disease Activity Index (BASDAI) has been used extensively in clinical trials and practice, and more recently, the AS Disease Activity Score (ASDAS) has been developed. Although a validated definition of clinical remission or LDA for BASDAI is currently unavailable ${ }^{23}$, certain cutoffs have been used in clinical trials and observational studies (BASDAI $<4^{24} ;<3$ or $\leq 3)^{25,26,27}$. For example, in the INFAST study, $76 \%$ of patients with early axSpA receiving infliximab plus naproxen achieved a BASDAI $<3$ at Week $28^{9}$. ASDAS offers a more objective assessment of disease activity because it includes
C-reactive protein (CRP), which is a marker of inflammation, and may predict structural progression ${ }^{28}$. ASDAS disease activity "states" (inactive disease: ASDAS < 1.3; moderate disease activity: ASDAS < 2.1) have been validated in a routine care population and a clinical trial population ${ }^{18}$, although further validation in relation to structural damage progression and quality of life is still required. The current lack of consensus on the optimal index of disease activity and cutoffs for disease activity states represents a major hurdle in the development of a treat-to-target approach in axSpA.

Whether current indices of disease activity are sufficient to provide an accurate measure of remission in a complex multifaceted disease such as axSpA is open to debate; the need for a measure that is simple enough to be applicable to clinical practice, while not being so stringent that it offers a target that is impossible to reach, must also be considered. Both ASDAS and ASAS PR fail to consider peripheral extraarticular manifestations of the disease, such as enthesitis and uveitis. ASAS PR also excludes objective signs of inflammation, such as CRP levels. Conversely, ASDAS does not include assessment of function, which might result in patients with extensive structural damage, who would never reach ASAS PR, achieving "inactive disease" 18 .

None of the composite disease measures developed to date consider the presence of inflammation on imaging. Magnetic resonance imaging (MRI) is important in the assessment of early axSpA, because inflammation and postinflammatory lesions are associated with new bone formation ${ }^{29}$. Discrepancies between "clinical" and "imaging" remission have been observed previously, with only a minority of patients achieving both concurrently ${ }^{22}$. Indeed, a suitable MRI scoring system and corresponding definition of remission is currently unavailable. Thus, is clinical remission alone a sufficiently rigorous measure of disease activity, and does it measure disease activity at all? Future studies are required to investigate this issue further, as well as the role of any residual inflammation in flares. Various definitions of flare have been proposed, yet none have been universally accepted and validated ${ }^{30}$. Further, both patients and physicians may have difficulty distinguishing mechanical overload from an inflammatory flare, so providing education on the key differences may be essential to ensure consistency in disease activity measurement.

Although retardation of structural progression is considered a key therapeutic goal, it is absent from current

Personal non-commercial use only. The Journal of Rheumatology Copyright (c) 2018. All rights reserved. 
Table 1. Achievement of ASAS partial remission and ASDAS inactive disease with pharmacologic treatment in clinical trials.

\begin{tabular}{|c|c|c|c|c|c|c|c|}
\hline Indication & Drug & Study & Timepoint & No. Patients & $\begin{array}{l}\text { ASAS Partial } \\
\text { Remission }(\%)\end{array}$ & $\begin{array}{l}\text { ASDAS Inactive } \\
\text { Disease }(\%)\end{array}$ & Reference \\
\hline Axial SpA & Naproxen & INFAST & Week 28 & 51 & 35.3 & 19.6 & $\begin{array}{l}\text { Sieper, et al. Ann Rheum Dis } \\
2014^{9}\end{array}$ \\
\hline \multirow[t]{2}{*}{$\mathrm{Nr}-\mathrm{axSpA}$} & Golimumab & - & Week 16 & 97 & 33 & 33 & $\begin{array}{l}\text { Sieper, et al. Arthritis } \\
\text { Rheumatol } 2015^{10}\end{array}$ \\
\hline & Adalimumab & ABILITY-1 & Week 12 & 91 & 16 & 24 & $\begin{array}{l}\text { Sieper, et al.Ann Rheum Dis } \\
2013^{11}\end{array}$ \\
\hline \multirow[t]{6}{*}{ AS } & Adalimumab & ATLAS & Week 12 & 208 & 20.7 & 36.5 & $\begin{array}{l}\text { van der Heijde, et al. Arthritis } \\
\text { Rheum } 2010^{13}\end{array}$ \\
\hline & Etanercept & - & Week 24 & 138 & 17 & - & $\begin{array}{l}\text { Davis, et al. Arthritis Rheum } \\
2003^{14}\end{array}$ \\
\hline & Golimumab & GO-RAISE & Week 14 & $50 \mathrm{mg}: 138$ & $50 \mathrm{mg}: \sim 22^{*}$ & $50 \mathrm{mg}: 20.3$ & $\begin{array}{l}\text { Inman, et al. Arthritis Rheum } \\
2008^{15}\end{array}$ \\
\hline & & & & 163 & 23.3 & 31.9 & $\begin{array}{l}\text { Machado, et al. Ann Rheum } \\
\text { Dis } 2011^{18}\end{array}$ \\
\hline & $\begin{array}{c}\text { Certolizumab } \\
\text { pegol }\end{array}$ & RAPID-axSpA & Week 12 & $\begin{array}{l}200 \mathrm{mg}: 65 \\
400 \mathrm{mg}: 56\end{array}$ & $\begin{array}{l}200 \mathrm{mg}: 20 \\
400 \mathrm{mg}: 19.6\end{array}$ & $\begin{array}{l}200 \mathrm{mg}: 21.5 \\
400 \mathrm{mg}: 16.1\end{array}$ & $\begin{array}{l}\text { Landewé R, et al. Ann Rheum } \\
\text { Dis } 2014^{12} \text { (mixed anti-TNF- } \\
\text { naive and anti-TNF-IR } \\
\text { population) }\end{array}$ \\
\hline & Secukinumab & MEASURE 1 & Week 16 & $\begin{array}{l}75 \mathrm{mg}: 124 \\
150 \mathrm{mg}: 125 \\
\text { TNF-naive } \\
75 \mathrm{mg}: 90 \\
150 \mathrm{mg}: 92 \\
\text { TNF-IR } \\
75 \mathrm{mg}: 34 \\
150 \mathrm{mg}: 33\end{array}$ & $\begin{array}{c}75 \mathrm{mg}: 16 \\
150 \mathrm{mg}: 15 \\
\text { TNF-naive } \\
75 \mathrm{mg}: 20 \\
150 \mathrm{mg}: 16.3 \\
\text { TNF-IR } \\
75 \mathrm{mg}: 5.9 \\
150 \mathrm{mg}: 12.1\end{array}$ & - & $\begin{array}{l}\text { Baeten, et al. N Engl J Med } \\
2015^{7} \text {; Baeten, } \text { et al. Arthritis } \\
\text { Rheumatol } 2015^{19}\end{array}$ \\
\hline
\end{tabular}

*Value estimated from graph in manuscript; data not cited in text. ASAS: Assessment of SpondyloArthritis international Society; ASDAS: Ankylosing Spondylitis Disease Activity Score; TNF-IR: tumor necrosis factor inhibitor inadequate responder; TNF-naive: TNF inhibitor naive; SpA: spondyloarthritis; nr-axSpA: nonradiographic axial SpA.

composite measures for axSpA assessment ${ }^{1,2}$. NSAID have shown some positive effects on spinal radiographic progression, which were more prominent in patients with increased CRP levels ${ }^{28,31}$. The anti-TNF therapies adalimumab, etanercept, and infliximab did not show inhibitory effects on radiographic progression in AS after 2 years of continuous therapy [change in modified Stoke Ankylosing Spondylitis Spine Score (mSASSS) $\sim 0.8-0.9]^{32,33,34}$. The latest data have nevertheless suggested that anti-TNF therapy may be effective in the long term ${ }^{27,35,36}$, especially when initiated early ${ }^{35}$. Indeed, recent data with certolizumab showed a change in mSASSS of -0.01 at 2 years in patients with nonradiographic axSpA, versus 0.67 in patients with $\mathrm{AS}^{37}$. Finally, recent evidence suggested a low rate of structural progression in patients with AS receiving secukinumab at 2 years $(\sim 80 \%$ no progression; change in mSASSS of $0.3)^{38}$. These data are not directly comparable with studies of anti-TNF therapies because of differences in study designs and populations ${ }^{38}$, and require further investigation in longterm controlled trials. Nevertheless, because high disease activity is associated with accelerated radiographic spinal progression $^{28}$, control of inflammation and disease activity may offer a sufficient surrogate for structural damage prevention. 
Prevention of further structural progression and low/minimal disease activity or ASDAS inactive disease may be an acceptable alternative treatment target in patients with existing irreversible structural progression. The patient's perspective should also be considered when setting treatment goals, although caution is recommended to avoid measures becoming too subjective. Treatment priorities for patients are pain and fatigue, as well as physical and social functioning ${ }^{39}$. Although pain is a central component of all existing indices of disease activity, sensitivity to pain may decrease over time; thus, the variability within patient-reported outcomes may represent an issue when aiming to measure remission consistently. Discrepancies between a patient's and a physician's view of remission are likely to exist because of differing perceptions of disease activity, disease severity, and treatment priorities. Comparing patient- and physician-reported remission in a real-life setting showed higher thresholds for patients (ASDAS $\leq 2.2$ ) versus physicians (ASDAS $\leq 2)^{40}$. It will be important to ensure patient understanding of the remission concept and its feasibility as a goal in the treat-to-target approach. A simple and easy-to-understand definition of remission is required, and effective patient-physician communication will be vital. Lessons can be learned from the ASAS Health Index and the Patient Acceptable Symptom State, which may be more easily understood by patients than remission.

Our main knowledge gap in targeting remission in axSpA is evidence from well-designed clinical trials that a treat-to-target approach is beneficial versus standard care. Although the TICOPA trial has shown this previously in psoriatic arthritis $^{41}$, data from ongoing similar studies in axSpA are awaited. While challenging to assess in international, multicenter studies, the cost of treating to target is another important consideration in the context of shrinking healthcare budgets and evidence that tight control of disease activity is more expensive in psoriatic arthritis and may be associated with an increased rate of adverse events ${ }^{41}$. Additionally, we do not yet know the minimum duration of remission that is beneficial for longterm outcomes in axSpA. Current guidelines from the European League Against Rheumatism recommend a sustained remission period of at least 6 months before tapering biologic therapy; more data are required to establish whether there is any association between length of time in remission and likelihood of flare ${ }^{2}$.

Strategy trials will be required to establish the best approach for reaching and sustaining remission. Patients should first be treated to remission, undergoing regular monitoring and adjustment of dose as necessary, before being randomized to different management strategies for the maintenance of sustained remission ( $>2 \mathrm{yrs}$ ). Ideally, such a trial should enroll only a homogeneous group of patients at a similar stage of early disease (disease duration $<3 \mathrm{yrs}$ ) and without advanced structural progression, with a longterm followup. Careful planning is essential to ensure that data collected provide answers to key issues relating to the optimum time at which to assess whether a treatment target has been reached, including predictors of response/ nonresponse; optimal dosing, sequences/combinations; predictors of flare; and strategies for dose tapering/reduction. Further studies are required to establish the role of physiotherapy in achieving remission, as a parallel or combination treatment to pharmacotherapy; its use in the maintenance of drug-free remission after biologic therapy tapering/ withdrawal may be particularly important.

A number of questions need to be answered before a treat-to-remission strategy can be incorporated into clinical practice (Table 2). The next step in targeting remission in

Table 2. Remission in axSpA research agenda.

\begin{tabular}{ll}
\hline Topics & Specific Questions \\
\hline Definitions of remission & $\begin{array}{l}\text { Do current definitions of remission include the necessary components? Is low disease } \\
\text { activity a suitable alternative target? } \\
\text { Do patients with irreversible structural damage require separate definitions of } \\
\text { remission/low disease activity from patients without structural damage? }\end{array}$ \\
& $\begin{array}{l}\text { Should additional outcomes, such as measures of structural damage or objective signs } \\
\text { of inflammation (MRI and CRP), be included in a treat-to-target strategy for axSpA? }\end{array}$ \\
& $\begin{array}{l}\text { How can the patient perspective be incorporated into the definitions of remission/low } \\
\text { disease activity? }\end{array}$ \\
& $\begin{array}{l}\text { Are we allowing enough time for patients to achieve remission once receiving } \\
\text { treatment? Is individual variability taken into account when assessing disease } \\
\text { activity? }\end{array}$ \\
foptimal treatment strategsion & $\begin{array}{l}\text { What is the best disease management approach for patients who do not achieve } \\
\text { remission while taking biologic therapy? } \\
\text { What is the optimal treatment strategy for patients who achieve remission while } \\
\text { taking biologic therapy for remission to be sustained? } \\
\text { What is the cost-benefit ratio of achieving remission if it is not sustained for at least } \\
\text { 2 years? }\end{array}$ \\
\hline
\end{tabular}

axSpA: axial spondyloarthritis; CRP: C-reactive protein; MRI: magnetic resonance imaging.

Personal non-commercial use only. The Journal of Rheumatology Copyright @ 2018 . All rights reserved. 
axSpA may be an evolution of the treat-to-target approach to focus on comprehensive disease control, including remission and prevention of structural damage. The ultimate aim is to develop a strategy, using the best available treatments to ensure the optimal outcome for patients with axSpA.

\section{XENOFON BARALIAKOS, MD,}

Associate Professor,

Department of Rheumatology,

Rheumazentrum Ruhrgebiet Herne,

Ruhr-University Bochum, Bochum, Germany;

FRANCIS BERENBAUM, $\mathrm{MD}, \mathrm{PhD}$,

Professor of Rheumatology,

Sorbonne University, INSERM UMR_S938,

DHU i2B, AP-HP, Saint-Antoine Hospital,

Paris, France;

ENNIO GIULIO FAVALLI, $\mathrm{MD}$,

Department of Rheumatology,

Gaetano Pini Institute,

Milan, Italy;

IGNAZIO OLIVIERI, MD,

Rheumatology Department,

Rheumatology Institute of Lucania (IRel), the Rheumatology Department of Lucania, San Carlo Hospital of Potenza and Madonna delle Grazie Hospital of Matera, Potenza and Matera, and the Basilicata Ricerca Biomedica Foundation, Potenza, Italy; BENEDIKT OSTENDORF, MD,

Prof. Dr. in Rheumatology, Poliklinik und Funktionsbereich für Rheumatologie and Hiller Forschungszentrum Rheumatologie, Universitätsklinikum Düsseldorf, Heinrich-Heine-Universität, Düsseldorf;

DENIS PODDUBNYY, $\mathrm{MD}, \mathrm{PhD}$

Professor of Rheumatology, Charité University Hospital, Berlin, Germany;

KURT DE VLAM, $\mathrm{MD}, \mathrm{PhD}$,

Principal Investigator, Department of Rheumatology, University Hospitals Leuven, Leuven, Belgium.

Dr. Ignazio Olivieri died July 28, 2017.

Novartis provided funding for the roundtable discussion. The authors thank Pierre Faugère, the patient representative, for his input during the initial roundtable discussion. Medical writing support was provided by Tia Bowman, Rachel Brown, and Ben Drever, medical writers from Seren Communications, an Ashfield Company, part of UDG Healthcare. Novartis provided the funding for the medical writing.

Address correspondence to Dr. X. Baraliakos, Associate Professor, Rheumazentrum Ruhrgebiet, Ruhr-University Bochum, Claudiusstr. 45, 44649 Herne, Germany. E-mail: xenofon.baraliakos@elisabethgruppe.de

\section{REFERENCES}

1. Smolen JS, Schöls M, Braun J, Dougados M, Fitzgerald O, Gladman D, et al. Treating axial spondyloarthritis and peripheral spondyloarthritis, especially psoriatic arthritis, to target: 2017 update to recommendations by an international task force. Ann Rheum Dis 2017 Jul 6 (E-pub ahead of print).

2. van der Heijde D, Ramiro $S$, Landewé $R$, Baraliakos $X$, van den Bosch F, Sepriano A, et al. 2016 update of the ASAS-EULAR management recommendations for axial spondyloarthritis. Ann Rheum Dis 2017;76:978-91

3. Landewé R, van Tubergen A. Clinical tools to assess and monitor spondyloarthritis. Curr Rheumatol Rep 2015;17:47.

4. Wendling D. Treating to target in axial spondyloarthritis: defining the target and the arrow. Expert Rev Clin Immunol 2015;11:691-3.

5. Anderson JJ, Baron G, van der Heijde D, Felson DT, Dougados M. Ankylosing spondylitis assessment group preliminary definition of short-term improvement in ankylosing spondylitis. Arthritis Rheum 2001;44:1876-86.

6. van der Heijde D, Baraf HS, Ramos-Remus C, Calin A, Weaver AL, Schiff M, et al. Evaluation of the efficacy of etoricoxib in ankylosing spondylitis: results of a fifty-two-week, randomized, controlled study. Arthritis Rheum 2005;52:1205-15.

7. Baeten D, Sieper J, Braun J, Baraliakos X, Dougados M, Emery P, et al. Secukinumab, an interleukin-17A inhibitor, in ankylosing spondylitis. N Engl J Med 2015;373:2534-48.

8. Zochling J, Braun J. Remission in ankylosing spondylitis. Clin Exp Rheumatol 2006;24(6 Suppl 43):S88-92.

9. Sieper J, Lenaerts J, Wollenhaupt J, Rudwaleit M, Mazurov VI, Myasoutova L, et al. Efficacy and safety of infliximab plus naproxen versus naproxen alone in patients with early, active axial spondyolarthritis: results from the double-blind, placebo-controlled INFAST study, Part 1. Ann Rheum Dis 2014;73:101-7.

10. Sieper J, van der Heijde D, Dougados M, Maksymowych WP, Scott $\mathrm{BB}$, Boice JA, et al. A randomized, double-blind,

placebo-controlled, sixteen-week study of subcutaneous golimumab in patients with active nonradiographic axial spondyloarthritis. Arthritis Rheumatol 2015;67:2702-12.

11. Sieper J, van der Heijde D, Dougados M, Mease PJ, Maksymowych WP, Brown MA, et al. Efficacy and safety of adalimumab in patients with non-radiographic axial spondyloarthritis: results of a randomised placebo-controlled trial (ABILITY-1). Ann Rheum Dis 2013;72:815-22.

12. Landewé R, Braun J, Deodhar A, Dougados M, Maksymowych WP, Mease PF, et al. Efficacy of certolizumab pegol on signs and symptoms of axial spondyloarthritis including ankylosing spondylitis: 24-week results of a double-blind randomised placebo-controlled phase 3 study. Ann Rheum Dis 2014;73:39-47.

13. van der Heijde D, Sieper J, Brown S, Lavie F, Panagan A. Comparison of ASAS partial remission and low ASDAS as indicators of remission-like states in ankylosing spondylitis [abstract]. Arthritis Rheum 2010;62 Suppl 10:S216.

14. Davis JC, van der Heijde D, Braun J, Dougados M, Cush J, Clegg $\mathrm{DO}$, et al. Recombinant human tumor necrosis factor receptor (etanercept) for treating ankylosing spondylitis. Arthritis Rheum 2003;48:3230-6.

15. Inman RD, Davis JC, van der Heijde D, Diekman L, Sieper J, Kim SI, et al. Efficacy and safety of golimumab in patients with ankylosing spondylitis: results of a randomized, double-blind, placebo-controlled, phase III trial. Arthritis Rheum 2008;58:3402-12.

16. van der Heijde D, Deodhar A, Braun J, Mack M, Hsu B, Gathany TA, et al. The effect of golimumab therapy on disease activity and health-related quality of life in patients with ankylosing spondylitis: 2-year results of the GO-RAISE trial. J Rheumatol 2015; 41:1095-103

17. van der Heijde D, Dijkmans B, Geusens P, Sieper J, DeWoody K, Williamson P, et al. Efficacy and safety of infliximab in patients with ankylosing spondylitis: results of a randomized, placebo-controlled trial (ASSERT). Arthritis Rheum 2005; 52:582-91. 
18. Machado P, Landewé R, Lie E, Kvien TK, Braun J, Baker D, et al. Ankylosing spondylitis disease activity score (ASDAS): defining cut-off values for disease activity states and improvement scores. Ann Rheum Dis 2011;70:47-53.

19. Baeten D, Blanco R, Geusens P, Sieper J, Jui-Cheng T, Martin R, et al. Secukinumab provides sustained improvements in the signs and symptoms of active ankylosing spondylitis in anti-TNF-naïve patients and those previously exposed to anti-TNF therapy: 52-week results from two randomized, double-blind, placebo-controlled phase 3 trials [abstract]. Arthritis Rheumatol 2015;67 Suppl $10: 2890$

20. Sieper J, Deodhar A, Marzo-Ortega H, Aelion JA, Blanco R, Jui-Cheng T, et al. Secukinumab efficacy in anti-TNF-naive and anti-TNF-experienced subjects with active ankylosing spondylitis: results from the MEASURE 2 Study. Ann Rheum Dis 2017; 76:571-92.

21. Barkham N, Keen HI, Coates LC, O'Connor P, Hensor E, Fraser $\mathrm{AD}$, et al. Clinical and imaging efficacy of infliximab in HLA-B27-positive patients with magnetic resonance imaging-determined early sacroiliitis. Arthritis Rheum 2009; 60:946-54.

22. Song IH, Hermann KG, Haibel H, Althoff CE, Listing J, Burmester $\mathrm{G}$, et al. Effects of etanercept versus sulfasalazine in early axial spondyloarthritis on active inflammatory lesions as detected by whole-body MRI (ESTHER): a 48-week randomised controlled trial. Ann Rheum Dis 2011;70:1257-63.

23. Sieper J. How to define remission in ankylosing spondylitis? Ann Rheum Dis 2012;71 Suppl 2:i93-5.

24. Braun J, Brandt J, Listing J, Zink A, Alten R, Golder W, et al Treatment of active ankylosing spondylitis with infliximab: a randomised controlled multicentre trial. Lancet 2002;359:1187-93.

25. Arends S, van der Veer E, Kamps FB, Houtman PM, Bos R, Bootsma $\mathrm{H}$, et al. Patient-tailored dose reduction of TNF- $\alpha$ blocking agents in ankylosing spondylitis patients with stable low disease activity in daily clinical practice. Clin Exp Rheumatol 2015; 33:174-80

26. Baraliakos X, Brandt J, Listing J, Haibel H, Sörensen H, Rudwaleit $\mathrm{M}$, et al. Outcome of patients with active ankylosing spondylitis after two years of therapy with etanercept: clinical and magnetic resonance imaging data. Arthritis Rheum 2005;53:856-63.

27. Baraliakos X, Listing J, Fritz C, Haibel H, Alten R, Burmester GR, et al. Persistent clinical efficacy and safety of infliximab in ankylosing spondylitis after 8 years - early clinical response predicts long-term outcome. Rheumatology 2011;50:1690-9.

28. Poddubnyy D, Protopopov M, Haibel H, Braun J, Rudwaleit M, Sieper J. High disease activity according to the Ankylosing Spondylitis Disease Activity Score is associated with accelerated radiographic spinal progression in patients with early axial spondyloarthritis: results from the GErman SPondyloarthritis Inception Cohort. Ann Rheum Dis 2016;75:2114-8.

29. Baraliakos X, Heldmann F, Callhoff J, Listing J, Appelboom T, Brandt $\mathrm{J}$, et al. Which spinal lesions are associated with new bone formation in patients with ankylosing spondylitis treated with anti-TNF agents? A long-term observational study using MRI and conventional radiography. Ann Rheum Dis 2014;73:1819-25.
30. Gossec L, Portier A, Landewe R, Etcheto A, Navarro-Compan V, Kroon F, et al. Preliminary definitions of 'flare' in axial spondyloarthritis, based on pain, BASDAI and ASDAS-CRP: an ASAS initiative. Ann Rheum Dis 2016;75:991-6.

31. Wanders A, van der Heijde A, Landewe R, Behier JM, Calin A, Olivieri I, et al. Nonsteroidal antiinflammatory drugs reduce radiographic progression in patients with ankylosing spondylitis: a randomized clinical trial. Arthritis Rheum 2005;52:1756-65.

32. van der Heijde D, Landewé R, Einstein S, Ory P, Vosse D, Ni L, et al. Radiographic progression of ankylosing spondylitis after up to two years of treatment with etanercept. Arthritis Rheum 2008;58:1324-31.

33. van der Heijde D, Landewé R, Baraliakos X, Houben H, van Tubergen A, Williamson $\mathrm{P}$, et al. Radiographic findings following two years of infliximab therapy in patients with ankylosing spondylitis. Arthritis Rheum 2008;58:3063-70.

34. van der Heijde D, Salonen D, Weissman BN, Landewé R, Maksymowych WP, Kupper H, et al. Assessment of radiographic progression in the spines of patients with ankylosing spondylitis treated with adalimumab for up to 2 years. Arthritis Res Ther 2009;11:R127.

35. Haroon N, Inman RD, Learch RJ, Weisman MH, Lee MJ, Rahbar $\mathrm{MH}$, et al. The impact of tumor necrosis factor $\alpha$ inhibitors on radiographic progression in ankylosing spondylitis. Arthritis Rheum 2013;65:2645-54

36. Maas F, Arends S, Brouwer E, Essers I, van der Veer E, Efde M, et al. Reduction in spinal radiographic progression in ankylosing spondylitis patients receiving prolonged treatment with TNF- $\alpha$ inhibitors. Arthritis Care Res 2017;69:1011-19.

37. van der Heijde D, Baraliakos X, Hermann K-G, Landewé R, Machado P, Maksymowych W, et al. Four year imaging outcomes in patients with axial spondyloarthritis treated with certolizumab pegol, including patients with ankylosing spondylitis and nonradiographic axial spondyloarthritis [abstract]. Arthritis Rheumatol 2016;68 Suppl 10:1042.

38. Braun J, Baraliakos X, Deodhar A, Baeten D, Sieper J, Emery P, et al. Effect of secukinumab on clinical and radiographic outcomes in ankylosing spondylitis: 2-year results from the randomised phase III MEASURE 1 study. Ann Rheum Dis 2017;76:1070-7.

39. Heiberg T, Lie E, van der Heijde D, Kvien TK. Sleep problems are of higher priority for improvement for patients with ankylosing spondylitis than for patients with other inflammatory arthropathies. Ann Rheum Dis 2011;70:872-3.

40. Godfrin-Valnet M, Prati C, Puyraveau M, Toussirot E, Letho-Gyselink H, Wendling D. Evaluation of spondylarthritis activity by patients and physicians: ASDAS, BASDAI, PASS, and flares in 200 patients. Joint Bone Spine 2013;80:393-8.

41. Coates LC, Moverley AR, McParland L, Brown S, Navarro-Coy N, O'Dwyer JL, et al. Effect of tight control of inflammation in early psoriatic arthritis (TICOPA): a UK multicentre, open-label, randomised controlled trial. Lancet 2015;386:2489-98.

J Rheumatol 2018;45:153-7; doi:10.3899/jrheum.170222 Personal non-commercial use only. The Journal of Rheumatology Copyright (C 2018. All rights reserved. 